\title{
UJI VALIDITAS ISI MODUL PROGRAM SMART BUYING UNTUK MENINGKATKAN KETERAMPILAN PENGAMBILAN KEPUTUSAN PEMBELIAN KONSUMEN DALAM MENCEGAH PENIPUAN BELANJA DARING PADA MAHASISWA
}

\section{VALIDITY TEST OF CONTENTS THE SMART BUYING PROGRAM MODULE TO IMPROVE CONSUMER PURCHASE DECISION MAKING SKILLS IN PREVENTING ONLINE SHOPPING FRAUD IN STUDENTS.}

\author{
${ }^{1}$ Ahmad Ricko Padesil, ${ }^{2}$ Nofrans Eka Saputra, ${ }^{3}$ Jelpa Periantalo \\ ${ }^{1,2,3}$ Department of Psychology, Jambi University/ rickopadesill@ gmail.com
}

\begin{abstract}
Introduction Shopping online carries risks, one of which is fraud. Fraud is caused by consumers lacking knowledge of the characteristics of fraud, low emotional control, such as being easily tempted by cheap prices and only interested in displaying images. Students who are in their late teens are vulnerable to becoming victims of online shopping scams. So a program is needed to improve student purchasing decision-making skills to prevent online shopping fraud.
\end{abstract}

Method This research uses a descriptive study with a 3D model (define, design, develop). The research data were obtained from three stages, namely the first stage is a needs analysis. The second stage is designing a frame of reference for the implementation of the program smart buying. The third stage is validating with the validator.

Results This study shows the results of the validation of the module content assessed by the validator, which have a score in the range of 0.58-0.83. The results of the validation of measuring instruments that were assessed by the validator had a range of numbers from 0.25 to 0.83

Conclusion and Recommendation Based on the results of the validity test of the module content of the program smart buying . is at a good level of content validity, meaning that there is a conformity of the content or material in each session of the program module smart buying with the objectives to be achieved.

Keywords: Module validity, Decision making skills, Program smart buying, Online shopping

\begin{abstract}
ABSTRAK
Pendahulan Belanja daring memiliki resiko salah satunya penipuan. Penipuan disebabkan konsumen kurang memiliki pengetahuan terhadap karakteristik penipuan, rendahya kontrol emosional seperti sangat mudah tergiur harga yang murah dan hanya tertarik dengan tampilan gambar. Mahasiswa yang berada pada usia remaja akhir rentan menjadi korban penipuan belanja daring. Sehingga diperlukan program guna meningkatkan keterampilan pengambilan keputusan pembelian mahasiswa untuk mencegah terjadiya penipuan belanja daring.

Metode Penelitian ini menggunakan studi deskriptif dengan model 3D (define, design, develop). Data penelitian diperoleh dari tiga tahapan yaitu tahapan pertama merupakan analisa kebutuhan. Tahapan kedua merancang kerangka acuan kegiatan pelaksanaan program smart buying. Tahapan ketiga melakukan validasi bersama validator.
\end{abstract}


Hasil Penelitian ini menunjukkan hasil validasi isi modul yang dinilai oleh validator yaitu memiliki angka skor dengan rentang 0,58-0,83. Hasil validasi alat ukur yang dinilai oleh validator memiliki rentang angka dari $0,25-0,83$.

Kesimpulan dan Saran Berdasarkan hasil uji validitas isi modul program smart buying berada pada tingkat validitas isi yang baik, artinya terdapat kesesuaian isi atau materi dalam tiap sesi modul program smart buying dengan tujuan yang hendak dicapai.

Kata Kunci: Validitas modul, keterampilan pengambilan keputusan, program smart buying, belanja daring.

\section{Pendahuluan}

Teknologi dalam perkembanganya dapat mengubah banyak hal salah satunya berbelanja. Transaksi dalam berbelanja saat ini tidak lagi mengaharuskan konsumen datang kepusat perbelanjaan bertatap muka dengan pedagang untuk melakukan transaki pembelian. Transaksi jual beli dapat dilakukan menggunakan komputer, laptop ataupun gawai yang difasilitasi dengan internet. Internet dapat memudahkan aktifitas berbelanja sehingga banyak masyarakat menggunakan internet untuk berbelanja.

Survei yang tercatat tahun 2018 di Indonesia pengguna internet mencapai 171,17 juta (APJII, 2019). 130,8 juta atau 98,6\% pengguna intenet Indonesia memanfaatkan internet untuk menawarkan atau mencari barang dan jasa, tercatat pula $63,5 \%$ atau 84,2 juta telah melakukan transaksi secara daring (APJII, 2016). Melihat hal ini tingginya angka pengguna internet di Indonesia dapat membuka peluang usaha yang ditangkap sebagian orang yang pada akhirnya memasarkan produk mereka melalui media yang tersedia internet.

Hal ini dapat memberikan keuntungan bagi penjual, seperti, menekan pengeluaran sewa tempat berjualan, pangsa pasar yang luas. Dengan transaksi jual beli daring, konsumen dapat berbelanja tidak perlu menghabiskan tenaga mengunjungi pusat perbelanjaan, lebih hemat waktu dan dapat dengan mudah memilih dan mencari produk yang dinginkan.

Adapun kelebihan dan kekurangan menurut Ananda (2018) kelebihanya konsumen dapat menikmati belanja setiap waktu karena toko daring selalu dapat diakses kapanpun, Memiliki jangkauan yang luas karena konsumen dapat membeli barang dan jasa kapanpun dan dimanapun. Barang barang yang ditawarkan juga bervariatif, tidak dipungut biaya pemasaran yang besar, target pemasaran sangatlah luas dan banyak, Tampilan toko dapat diatur dan disesuaikan sesuai dengan keinginan penjual, memiliki sistem endorse yang sangat membantu dalam mengkatkan penjualan.

Transaksi belanja daring juga memiliki kekurangan seperti konsumen tidak bisa merasakan, atau mengetahui kualitas dari produk yang akan dibeli, konsumen hanya bisa memberikan penilaian produk yang dibutuhkan melalui gambar dan deskripsi produk yang penjual tulis, pembeli harus cakap dalam menggunakan teknologi, pembeli yang tidak paham terhadap barang yang akan dibeli, tidak paham sistem pembelian dan pengembalian barangnya, dapat mengakibatkan banyak kerugian bagi konsumen, barang yang dibelipun tidak semua dapat dikembalikan maka dari itu konsumen harus teliti dan paham konsekuensi yang akan didapat karena belanja daring rentan terhadap penipuan.

Menurut Anwar (Rusmana, 2015) Penipuan merupakan suatu perbuatan individu atau kelompok yang membuat keadaan palsu seakan akan nyata dengan cara melakukan bujuk rayu, menggunakan kata dusta, identitas palsu untuk membuat orang menjadi tak berdaya untuk menolak kenyataan tersebut hingga mempercayai bahwa keadaan tersebut benar adanya hingga pelaku penipuan mendapatkan 
Uji Validitas Isi Modul Program Smart Buying untuk Meningkatkan Keterampilan

Pengambilan Keputusan Pembelian Konsumen dalam Mencegah Penipuan Belanja

Daring pada Mahasiswa

seuatu yang diingkan dari korban yang menjadi target penipuan.

Berdasarkan catatan Kasperskylab jumlah angka penipuan keuangan daring terus mengalami peningatan. Melalui survei di 26 negara, Indonesia masuk dalam tiga besar sebagai negara dengan konsumen yang sering menjadi korban penipuan daring. Indonesia menduduki peringkat pertama dengan persentase $26 \%$, diikuti Vietnam 25\%, dan India 24\%. (Kure, 2016). Berdasarkan catatan Otoritas Jasa
Keuangan pada tahun 2019 jumlah aduan masyarakat terkait penipuan belanja daring atau daring shop mencapai 19.000 ribu. Rata-rata aduan yang masuk sebagian besar adalah barang belanja tidak dikirim setelah pembayaran dilakukan (Putra, 2019)

Berdasarkan catatan Ditreskrimsus Polda Jambi, Pada 2019 terdapat 12 Pengaduan terkait penipuan belanja daring yang digambar pada tabel berikut :

Tabel 1. Data Laporan Pengaduan Penipuan Belanja Daring di Polda Jambi Sumber : Ditreskrimsus Polda Jambi (2019)

\begin{tabular}{ccccccc}
\hline \multicolumn{2}{c}{ Jenis Kelamin } & & \multicolumn{2}{l}{ Pekerjaan } & \multicolumn{3}{c}{$\begin{array}{c}\text { Media Sosial Yang } \\
\text { Digunakan }\end{array}$} \\
\hline Wanita & Pria & Wiraswata & Pelajar /Mahasiwa & Lainya & Facebook Instagram & Web \\
\hline 8 & 4 & 2 & 3 & 5 & 3 & 7 \\
\hline Jumlah & & & & 12 & & \\
\hline
\end{tabular}

Data menyatakan bahwa dari 12 laporan kasus penipuan belanja daring. Telah memakan korban dengan usia 18-25 tahun dengan jumlah 4 orang, 26-40 tahun 6 orang, 41 tahun keatas 3 orang, dengan pekerjaan wiraswasta 2 orang, Mahasiswa 3 orang dan pekerjaan lainnya 5 Orang. Alamat korban tercatat berdomisili berada di kecamatan yang berada di Kota Jambi dan media sosial yang digunakan dalam belanja daring facebook sebanyak 1, facebook 3 dan paling tinggi instagram dengan angka 7.

Berdasarkan uraian angka penipuan yang dipaparkan, Transaksi jual beli daring

tetap mempunyai kelemahan sehingga menyebabkan timbulnya korban. Dalam transaksi jual beli daring konsumen tidak bisa melihat barangnya secara langsung dan membuka peluang bagi pelaku kejahatan dalam melancarkan aksinya. Pelaku memanfaatkan kemudahan dalam melakukan penipuan dengan berbagai macam modus. Maka dari itu konsumen dituntut harus waspada terhadap modus kejahatan.

Adapun hal-hal yang berkaitan dengan keamanan dilakukan pemerintah dalam menindak tegas kasus penipuan ini sekaligus melindung konsumen dengan cara membuat pengaturan hukum. Tindak pidana penipuan dapat dijerat dengan Pasal "378 KUHP sebagai tindak pidana penipuan atau Pasal 28 ayat (1) UU ITE tentang pengaturan mengenai penyebaran berita bohong dan menyesatkan yang merugikan konsumen. Atau dapat dijerat berdasarkan kedua pasal itu sekaligus yaitu 378 KUHP Pasal 28 ayat (1) pasal 45 ayat (1) UU No 11 Tahun 2008 tentang penipuan dan atau kejahatan ITE”. (Sumenge, 2013).

Dalam menentukan toko belanja daring terdapat hal-hal yang harus diperhatikan untuk mengidentifikasi ciri penipu jual beli daring. Jaya (2012) menyebutkan harga produk terlampau murah dibanding harga produk yang normal pada umumnya, umumnya pedagang tidak beralamat di Jakarta atau kota besar, menolak atau tidak melakukan sistem pembayaran rekening bersama dengan alasan tidak mau repot, mendolak COD atau pembelian dengan bertemu secara langsung, bukti pengiriman dan gambar produk biasanya merupakan gambar palsu yang didapatkan dari banyak forum.

Adapun yang harus dilakukan menurut Amelia (2016) Dengan mencari 
testimonial penjual melalui mesin pencari, perhatikan jumlah pengikut, tunai saat pengiriman, menggunakan Layanan escrow tepercaya untuk pembayaran, hubungi nama layanan atau kombinasi nomor, periksa opsi penandaan penjual.

Menurut Rusmana (2015) Penipuan daring dapat terjadi dikarenakan strategi framing atau pembingkaian oleh pelaku penipuan, dengan membuat media sosial yang mampu menciptakan kesan nyata pada korban penipuan. Menurut Nurwita (2015) ketidak hati hatian konsumen saat berbelanja menjadi penyebab utama dari konsumen sepert sehingga sangat gampang terbuai dengan harga sangat murah tanpa mengecek kualitas toko untuk dipercayai.

Penelitian yang dilakukan oleh Button et al., (2014). Korban memberikan keterangan tenttang bagaimana bisa mereka menjadi korban penipuan dikarenakan penipu menciptakan kesan bahwa kejadian penipuan itu seperti asli dan sulit diidentifikasi Berdasarkan penelitian Office of Fair Trading (2009) salah satu faktor yang memicu kesalahan konsumen dalam berbelanja daring sehingga mudah mengalami penipuan adalah karena kurangnya kontrol emosional.

APJII (2019) mencatat mahasiswa yang menggunakan internet sebanyak $92,1 \%$. Rata-rata usia mahasiswa 18-21 tahun yang mana diusia tersebut termasuk usia remaja. Teori perkembangan masa remaja adalah masa dimana individu dihadapkan pada kondisi lebih banyak dihadapkan pada situasi pengambilan keputusan, jika dibandingkan remaja yang lebih tua, tingkat pengambilan keputusanya lebih baik dari remaja muda, namun tingkat pengambilan keputusan remaja tetap jauh dari sempurna, karena emosi pada saat remaja cendrung kuat, dengan kondisi demikian emosi seringkali menghambat pengambilan keputusan (Santrock, 2012).

Dalam mengambil keputusan untuk berbelanja konsumen remaja memiliki karakteristik cenderung dapat dengan mudah dipengaruhi oleh penjual, gampang terpengaruh oleh iklan, melihat hanya pada tampilan, boros, tidak realistis, dan sangat mudah dipengaruhi (Munandar, 2014).

Melihat hal itu peneliti melihat konsumen remaja berpeluang menjadi korban penipuan belanja daring dan peneliti mencoba untuk mensurvey mahasiswa Program Studi Diploma (Perpajakan, Akuntansi dan Manajemen Pemasaran) Fakultas Ekonomi dan Bisnis Universitas Jambi apakah terdapat mahasiswa yang menjadi korban penipuan belanja daring. Berdasarkan hasil survey yang peneliti lakukan didapatkan 37 orang mahasiswa Diploma Feb Universitas Jambi pernah tertipu belanja daring.

Perempuan merupakan korban penipuan terbanyak yaitu $73 \%$ dan LakiLaki 27\%. Media terbanyak terdapat penipuan yaitu Instagram $32,4 \%$, Shopee 29,7\% dan Facebook 16,2\%. Bentuk Penipuan yang terbesar karena barang tidak sesuai dengan difoto sebanyak $64,9,7 \%$, Barang tidak dikirim 24,3\%. Alasan tertipu dikarenakan kurangnya kehati hatian karena melihat gambar yang menarik, Tidak bisa membedakan toko daring yang baik dan terindikasi melakukan kecurangan dan harga yang murah

Melihat angka penipuan belanja daring tetap terus terjadi walaupun telah ada payung hukum yang melindungi konsumen disisi lain perlu adanya tindakan untuk meningkatkan keterampilan pengambilan keputusan guna mencegah terjadinya penipuan belanja daring agar tidak terjadi secara berulang-ulang. Nurwita (2015) membuat sebuah perancangan kampanye waspada penipuan saat belanja daring mengunakan program smart buying seperti dengan, logo, video teaser, ambient media, vidio blog, pop up ads, poster, flyer, dan iklan majalah, bandau dan street banner, website, media Sosial.

Untuk meningkatkan keterampilan pengambilan keputusan dapat ditingkatkan melalui pelatihan dan Diskusi. Menurut Noe (2009) tujuan pelatihan adalah untuk meningkatkan keterampilan (skill), perilaku (attitude) dan pengetahuan (knowledge) agar seseorang dapat menjalankan fungsi 
dan tugasnya dengan kekuatam penuh. Lorains et al., (2013) menunjukan Pemain elit sepak bola australia yang dilatih menggunakan real time dengan vidio game meningkatkan pengambilan keputusan mereka dalam gerakan memberikan umpan dan meningkatkan kinerja lebih awal dalam intervensi pelatihan dibandingkan dengan mereka yang dilatih dalam kecepatan normal.

Penelitian yang dilakukan oleh Schweizer et al., (2011) Pelatihan berbasis video dapat meningkatkan keterampilan pengambilan keputusan intuitif wasit sepakbola. Santrock (2012) mengatakan bahwa strategi yang dapat dilakukan guna meningkatkan keterampilan pengambilan keputusan adalah dengan memberikan peluang kepada individu untuk lebih banyak terlibat dalam diskusi pemecahan masalah kelompok.

Maka dari itu peneliti tertarik untuk membuat program pelatihan untuk meningkatkan keterampilan pengambilan keputusan pembelian konsumen terutama pada mahasiswa agar terhindar dari penipuan berbelanja daring melalui Program smart buying. Program smart buying sendiri merupakan pelatihan untuk meningkatkan keterampilan pengambilan keputusan pembelian yang terdiri dari tiga sesi yakni, pemberian materi, beberapa media, serta diskusi. Berdasarkan uraian di atas peneliti tertarik untuk melakuan penelitian mengenai validasi isi modul program smart buying untuk meningkatkan keterampilan pengambilan keputusan pembelian yang akan diuji keefektifan modul sehingga dapat dijadikan bahan acuan untuk meningkatkan keterampilan pengambilan keputusan pembelian konsumen dalam mencegah terjadinya penipuan belanja daring pada mahasiswa.

\section{Metode}

Prosedur pengembangan dalam penelitian validasi modul yang digunakan merupakan modifikasi dari model 4D yang dikemukakan oleh Thiagarajan (Sugiyono, 2019) yang terdiri dari empat prosedur yaitu define, design, develop, dan dissemination. Prosedur pengembangan dalam penelitian validasi modul ini dimodifikasi menjadi model 3D hanya sampai pada tahap uji coba terbatas (develop) dengan menggunakan metode studi deskriptif. Mengacu pada hal tersebut, maka validasi modul program Smart Buying untuk meningkatkan keterampilan pengambilan keputusan pembelian konsumen pada mahasiswa dilakukan melalui tiga prosedur, yaitu:

\section{Tahap Pertama (define)}

Prosedur penelitian tahap pertama ini, dilakukan pada saat menelusuri gambaran permasalahan dilapangan mengenai keterampilan pengambilan keputusan pembelian mahasiswa melalui pengisian kuesioner pada Mahasiswa Diploma Fakultas Ekonomi dan Bisnis Universitas Jambi. Untuk melihat gambaran penipuan yang telah dialami mahasiswa yaitu siapa lebih banyak tertipu, bentuk penipuan yang dialami, dari media apa mereka tertipu hingga sebab mereka tertipu. Analisis yang digunakan pada penelitian ini yaitu menggunakan analisis literatur mengenai program smart buying, keterampilan pengambilan keputusan dan mahasiswa.

\section{Tahap Kedua (design)}

Pada tahap kedua dalam penyusunan modul ini yaitu menentukan metode dalam Program Smart Buying dan merancang urutan kegiatan tersebut. Kegiatan dalam Program smart buying ini terdiri dari tiga sesi, yang mencakup tiga aspek dari keterampilan pengambilan keputusan pembelian, yaitu aspek intelligence pemberian materi mengenai belanja daring hingga penipuan, ciri toko daring dan panduan mengenal toko belanja daring, aspek design pemberian media gambar, dan pemberian media kartu troble kredible memuat aspek choice, Program ini merupakan program yang telah dimodifikasi pelaksanaannya sesuai dengan kebutuhan assessment. 


\section{Tahap Ketiga (develop)}

Tahap ketiga merupakan tahapan yang menunjukkan bahwa modul yang telah dirancang oleh peneliti telah divalidasi oleh ahli pakar atau validator yang profesional dibidangnya sesuai dengan topik peneliti, modul yang telah disusun dinilai oleh tiga orang validator yang dipilih secara purposive yaitu Psikolog pendidikan, Psikolog industri dan organisasi, yayasan lembaga konsumen indonesia. Hasil evaluasi dari validator digunakan peneliti untuk menilai dan merevisi modul yang telah dibuat

\section{HASIL}

\section{Tahap pertama (define)}

Prosedur penelitian tahap pertama ini, dilakukan pada saat menelusuri gambaran permasalahan di lapangan mengenai keterampilan pengambilan keputusan pembelian mahasiswa melalui pengisian kuesioner pada mahasiswa diploma Fakultas Ekonomi dan Bisnis Universitas Jambi. Untuk melihat gambaran penipuan yang telah dialami mahasiswa yaitu siapa lebih banyak tertipu, bentuk penipuan yang dialami, dari media apa mereka tertipu hingga sebab mereka tertipu. Analisis yang digunakan pada penelitian ini yaitu menggunakan analisis literatur mengenai program smart buying, keterampilan pengambilan keputusan dan mahasiswa.

\section{a. Program smart buying}

Program smart buying merupakan kegiatan pelatihan yang bertujuan untuk meningkatkan keterampilan pengambilan keputusan pembelian konsumen agar dapat mencegah penipuan belanja daring. Program ini memuat beberapa sesi kegiatan yaitu diawali dengan pemberian informasi yang memaparkan materi tentang belanja daring, penipuan, ciri toko daring yang baik dan penipu serta panduan mengenali toko belanja daring. Selain itu terdapat kegiatan dengan menggunakan beberapa media seperti media gambar, kartu troble kredible.

\section{b. Keterampilan keputusan}

Keterampilan

pengambilan menggunakan logikanya untuk menentukan suatu keputusan yang akan diambil guna memecahkan masalah yang dihadapi melalui proses-proses menelaah informasi, memperhatikan kekurangan dan kelebihan tiap alternatif, menyeleksi, hingga sampai pada mengambil keputusan final (Iskandar, 2014).

\section{c. Mahasiswa}

Mahasiswa merupakan seseoarang yang sedang berproses menimba ilmu pada tingkat perguruan tinggi, entah itu perguruan tinggi negeri maupun swasta atau setingkat dengan perguruan tinggi. Mahasiswa dinilai memiliki tingkat kecerdasan yang tinggi, cerdas dalam berpikir dan memiliki perencanaan dalam melaksanakan suatu tindakan (Siswoyo, 2007).

Rata-rata Usia mahasiswa 18-21 tahun yang mana diusia tersebut termasuk usia remaja. Menurut (Munandar, 2014) Karakteristik konsumen yang dimiliki remaja yaitu, remaja cenderung dapat dengan mudah dipengaruhi oleh penjual, gampang terpengaruh oleh iklan, melihat hanya pada tampilan, boros, tidak realistis, dan sangat mudah dipengaruhi.

\section{Tahap kedua (design)}

Pada tahap kedua dalam penyusunan modul ini yaitu menentukan metode dalam program smart buying dan merancang urutan kegiatan tersebut. Kegiatan dalam program smart buying ini terdiri dari tiga sesi, yang mencakup tiga aspek dari keterampilan pengambilan keputusan pembelian, yaitu aspek intelligence pemberian materi mengenai belanja daring hingga, penipuan, ciri toko daring dan panduan mengenal toko belanja daring, 
Uji Validitas Isi Modul Program Smart Buying untuk Meningkatkan Keterampilan Pengambilan Keputusan Pembelian Konsumen dalam Mencegah Penipuan Belanja

Daring pada Mahasiswa

aspek design pemberian media gambar, dan pemberian media kartu troble kredible memuat aspek choice, program ini merupakan program yang telah dimodifikasi pelaksanaannya sesuai dengan kebutuhan assessment.

a. Intervensi sesi 1 adalah Pemberian materi kepada peserta berupa kegiatan edukasi dengan memberikan pengetahuan mengenai belanja daring, penipuan, ciri ciri toko daring yang baik dan terindikasi melakukan penipuan dan panduan mengenali toko daring.

b. Intervensi sesi 2 memberikan media Gambar. Media gambar merupakan sebuah buku yang berisi kumpulan gambar yang terindikasi melakukan kecurangan, peserta diminta untuk memilih satu gambar yang tidak terindikasi melakukan kecurangan diantara pilihan gambar lainya.

c. Intervensi sesi 3, Pemberian kartu troble kredible, Peserta diberikan sebuah kartu yang berisi ilustrasi tenttang proses seorang tokoh dalam menentukan satu toko daring saat berbelanja. Kemudian peserta diminta untuk menganalisis dengan menjawab pertanyaan yaitu apakah proses belanja tetap dilanjutkan, alasan dan toko seperti apa yang harusnya dipilih.

\section{Tahap ketiga (develop)}

Penilaian uji validitas modul dilakukan melalui diskusi dengan subject matter expert (SME) baik secara daring maupun luring disesuaikan dengan kesediaan dari tiap validator. Untuk proses yang dilakukan secara langsung, peneliti menghubungi dan menemui validator secara tatap muka, berdiskusi mengenai saran dan masukan untuk perbaikan modul, kemudian menerima hasil subject matter expert dan Aiken's V alat ukur.

Sedangkan untuk proses yang dilakukan secara daring, diskusi dilakukan menggunakan aplikasi zoom, kemudian hasil Aiken's V dikirimkan secara daring melalui aplikasi pesan instan whatsapp ataupun melalui gmail. Berdasarkan proses yang telah dilakukan didapakan hasil penilaian modul dan alat ukur yang diberika validator dengan penjelasan sebagai berikut :

Tabel 2. Hasil Validasi Modul

\begin{tabular}{|c|c|c|c|c|c|c|c|c|c|c|c|c|c|}
\hline \multirow{2}{*}{ Sesi } & \multirow{2}{*}{ No Item } & \multicolumn{6}{|c|}{ Skor } & \multirow{2}{*}{$\begin{array}{l}\text { Total } \\
\text { Nilai }\end{array}$} & \multirow[t]{2}{*}{$\sum \mathrm{s}$} & \multirow[t]{2}{*}{$\mathbf{n}$} & \multirow[t]{2}{*}{ c-1 } & \multirow[t]{2}{*}{ Validitas } & \multirow[t]{2}{*}{ Kategori } \\
\hline & & P1 & $\mathbf{S}$ & $\mathbf{P 2}$ & $\mathbf{s}$ & P3 & $\mathbf{s}$ & & & & & & \\
\hline \multirow[t]{3}{*}{ Sesi I } & 1 & 3 & 2 & 5 & 4 & 5 & 4 & 13 & 10 & 3 & 4 & 0,83 & Sangat Tinggi \\
\hline & 2 & 3 & 2 & 4 & 3 & 5 & 4 & 12 & 9 & 3 & 4 & 0,75 & Tinggi \\
\hline & 3 & 3 & 2 & 3 & 2 & 5 & 4 & 11 & 8 & 3 & 4 & 0,67 & Tinggi \\
\hline \multirow[t]{2}{*}{ Sesi II } & 4 & 3 & 2 & 4 & 3 & 5 & 4 & 12 & 9 & 3 & 4 & 0,75 & Tinggi \\
\hline & 5 & 2 & 1 & 3 & 2 & 5 & 4 & 10 & 7 & 3 & 4 & 0,58 & Sedang \\
\hline Sesi III & 6 & 2 & 1 & 4 & 3 & 5 & 4 & 11 & 8 & 3 & 4 & 0,67 & Tinggi \\
\hline
\end{tabular}

Rentang angka $\mathrm{V}$ yang dapat diperoleh adalah 0-1,00. Setiap skor V yang melebihi dari angka 0,50 dapat dianggap sebagai indikasi adanya validitas isi modul yang baik (Azwar, 2018). Skor angka yang ditampilkan dalam tabel 2 dapat diinterpretasikan sebagai koefisien yang tinggi. Data tabel 2 menunjukkan skor V bergerak dari angka 0,58-0,83 dengan kategori tinggi sampai sangat tinggi. Sub bagian modul pada masing-masing sesi dari program smart buying memiliki isi yang baik dengan rentang skor di atas 0,50 . 
Tabel 3. Hasil Validasi Alat Ukur

\begin{tabular}{|c|c|c|c|c|c|c|c|c|c|c|c|c|c|}
\hline \multirow{2}{*}{ Aspek } & \multirow{2}{*}{ No Item } & \multicolumn{6}{|c|}{ Skor } & \multirow{2}{*}{$\begin{array}{l}\text { Total } \\
\text { Nilai }\end{array}$} & \multirow{2}{*}{$\sum \mathrm{s}$} & \multirow{2}{*}{$\mathbf{n}$} & \multirow{2}{*}{\multicolumn{2}{|c|}{ c-1 Validitas }} & \multirow{2}{*}{ Kategori } \\
\hline & & P1 & $\mathbf{S}$ & $\mathbf{P 2}$ & $\mathbf{s}$ & P3 & $\mathbf{s}$ & & & & & & \\
\hline \multirow{10}{*}{ Intelligence } & 1 & 4 & 3 & 3 & 2 & 5 & 4 & 12 & 9 & 3 & 4 & 0,75 & Tinggi \\
\hline & 2 & 1 & 0 & 2 & 1 & 3 & 2 & 6 & 3 & 3 & 4 & 0,25 & Rendah \\
\hline & 3 & 3 & 2 & 1 & 0 & 4 & 3 & 8 & 5 & 3 & 4 & 0,42 & Cukup \\
\hline & 4 & 1 & 0 & 3 & 2 & 3 & 2 & 7 & 4 & 3 & 4 & 0,33 & Rendah \\
\hline & 5 & 4 & 3 & 4 & 3 & 5 & 4 & 13 & 10 & 3 & 4 & 0,83 & Sangat Tinggi \\
\hline & 6 & 1 & 0 & 3 & 2 & 3 & 2 & 7 & 4 & 3 & 4 & 0,33 & Rendah \\
\hline & 7 & 4 & 3 & 4 & 3 & 4 & 3 & 12 & 9 & 3 & 4 & 0,75 & Tinggi \\
\hline & 8 & 1 & 0 & 3 & 2 & 3 & 2 & 7 & 4 & 3 & 4 & 0,33 & Rendah \\
\hline & 9 & 2 & 1 & 4 & 3 & 4 & 3 & 10 & 7 & 3 & 4 & 0,58 & Cukup \\
\hline & 10 & 4 & 3 & 3 & 2 & 3 & 2 & 10 & 7 & 3 & 4 & 0,58 & Cukup \\
\hline \multirow{8}{*}{ Design } & 11 & 1 & 0 & 4 & 3 & 3 & 2 & 8 & 5 & 3 & 4 & 0,42 & Cukup \\
\hline & 12 & 4 & 3 & 4 & 3 & 5 & 4 & 13 & 10 & 3 & 4 & 0,83 & Sangat Tinggi \\
\hline & 13 & 4 & 3 & 4 & 3 & 4 & 3 & 12 & 9 & 3 & 4 & 0,75 & Tinggi \\
\hline & 14 & 2 & 1 & 4 & 3 & 3 & 2 & 9 & 6 & 3 & 4 & 0,50 & Cukup \\
\hline & 15 & 4 & 3 & 4 & 3 & 5 & 4 & 13 & 10 & 3 & 4 & 0,83 & Sangat Tinggi \\
\hline & 16 & 1 & 0 & 3 & 2 & 3 & 2 & 7 & 4 & 3 & 4 & 0,33 & Rendah \\
\hline & 17 & 1 & 0 & 4 & 3 & 5 & 4 & 10 & 7 & 3 & 4 & 0,58 & Cukup \\
\hline & 18 & 1 & 0 & 4 & 3 & 3 & 2 & 8 & 5 & 3 & 4 & 0,42 & Cukup \\
\hline \multirow{4}{*}{ Choice } & 19 & 2 & 1 & 4 & 3 & 5 & 4 & 11 & 8 & 3 & 4 & 0,67 & Tinggi \\
\hline & 20 & 3 & 2 & 4 & 3 & 5 & 4 & 12 & 9 & 3 & 4 & 0,75 & Tinggi \\
\hline & 21 & 3 & 2 & 4 & 3 & 5 & 4 & 12 & 9 & 3 & 4 & 0,75 & Tinggi \\
\hline & 22 & 2 & 1 & 4 & 3 & 3 & 2 & 9 & 6 & 3 & 4 & 0,50 & Cukup \\
\hline
\end{tabular}

Rentang angka $\mathrm{V}$ yang dapat diperoleh adalah 0-1,00. Setiap skor V yang melebihi dari angka 0,30 maka dapat disimpulkan bahwa butir instrumen tersebut dinyatakan valid (Sugiyono, 2017). Skor angka yang ditampilkan pada instrumen alat ukur keterampilan pengambilan keputusan pembelian dalam tabel 3 dapat diinterpretasikan sebagai koefisien yang bergerak dari kategori rendah hingga sangat tinggi. Data tabel 3 menunjukkan skor $\mathrm{V}$ bergerak dari angka 0,25-0,83 sehingga menunjukkan bahwa terdapat 5 butir instrumen alat ukur dengan kategori rendah, 8 butir instrumen alat ukur dengan kategori cukup, 6 butir instrumen alat ukur dengan kategori tinggi dan 3 butir instrumen alat ukur dengan kategori sangat tinggi.

Berdasarkan uji validasi alat ukur pula terdapat 1 aitem instrumen alat ukur keterampilan pengambilan keputusan pembelian konsumen yang gugur validator ahli yang memberikan penilaian validasi alat ukur tersebut adalah psikolog industri dan organisasi, psikolog pendidikan, dan ketua yayasan lembaga konsumen Indonesia (YLKI).

\section{Pembahasan}

Penelitian ini merupakan penelitian riset validasi modul yang dilakukan mengikuti prosedur pengembangan model 4D yang dikemukakan oleh Thiagarajan (Sugiyono, 2019) yang terdiri dari empat prosedur yaitu define, design, develop, dan dissemination. Prosedur pengembangan dalam penelitian validasi modul ini dimodifikasi menjadi model 3D hanya sampai pada tahap uji coba terbatas (develop) dengan menggunakan metode studi deskriptif. Uji validasi modul dengan expert judgement menghasilkan modul yang dapat menjawab permasalahan penelitian dan siap untuk diuji cobakan.

Permasalahan yang diangkat berasal dari penipuan belanja daring yang terjadi pada mahasiswa. Penipuan ini disebabkan ketidak hati hatian dan ketidakmampuan mahasiswa itu sendiri dalam membedakan toko belanja daring yang terindikasi 
Uji Validitas Isi Modul Program Smart Buying untuk Meningkatkan Keterampilan Pengambilan Keputusan Pembelian Konsumen dalam Mencegah Penipuan Belanja

melakukan penipuan dan baik. Menindaklanjuti permasalahan yang ada, maka dirancanglah sebuah modul program smart buying untuk meningkatkan keterampilan pengambilan keputusan pembelian konsumen agar mencegah penipuan belanja daring terutama pada mahasiswa. Penyusunan modul ini dilakukan dengan menentukan metode kegiatan, merancang sesi kegiatan yang disesuaikan dengan aspek keterampilan pengambilan keputusan pembelian, hingga merancang alat ukur penelitian.

Modul merupakan sebuah paket instruksi yang disesuaikan dengan kebutuhan peserta dalam menguasai suatu materi. Oleh karena itu, sebelum dapat digunakan maka diperlukan uji validitas pada modul tersebut. Pada penelitian ini dilakukan uji validasi modul oleh empat orang judgement expert yaitu psikolog industri dan organisasi, psikolog pendidikan, dan ketua yayasan lembaga konsumen indonesia.

Berdasarkan hasil uji validitas modul, yang telah dilakukan pada modul program smart buying memiliki validitas isi yang baik dengan skor validitas oleh expert judgement pada setiap sesinya berkisar dari 0,58-0,83. Modul dapat dikatakan valid berdasarkan validitas isi karena skor validitas berada di atas 0,50. Namun dengan alat ukur penelitian berupa skala keterampilan pengambilan keputusan pembelian, nilai Aiken's $V$ terdapat satu aitem yang berada di bawah 0,30 dengan kata lain tidak valid atau gugur dan 21 aitem lainya berada diatas 0,3 atau valid dengan angka berkisar antara 0,33-0,83.

Penelitian ini sejalan dengan penelitian yang dilakukan oleh (Schweizer et al., 2011) yang menunjukkan pelatihan berbasis video dapat meningkatkan keterampilan pengambilan keputusan intuitif wasit sepakbola. Menurut Noe (2009) tujuan pelatihan adalah untuk meningkatkan keterampilan (skill), perilaku (attitude) dan pengetahuan (knowledge) agar seseorang dapat menjalankan fungsi dan tugasnya dengan kekuatan penuh.
Maloney (2007) berpendapat bahwa dalam menentukan suatu keputusan, elaborasi dan klarifikasi terkait informasiinformasi yang diperlukan sangat penting. Hal ini dapat dicapai dengan menghadapkan seseorang dengan keadaan nyata dari masalah yang ia hadapi. Sesuai dengan hal tersebut, modul smart buying disusun dengan menghadapkan peserta pada kondisi penipuan belanja daring agar peserta dapat menerapkan secara langsung keterampilan pengambilan keputusan menghadapi kondisi penipuan tersebut.

Penyusunan modul disesuaikan dengan subjek modul yaitu mahasiswa. Modul disusun dengan media yang menarik seperti gambar dan kartu. Hal ini sesuai dengan penelitian terdahulu dari (Nurwita, 2015) mengenai perancangan kampanye waspada penipuan belanja daring, dimana media yang digunakan berupa logo, video, dan poster untuk subjek mahasiswa. Selain itu, penelitian dari (Kurniawati et al., 2018) menggunakan media berbasis visual seperti video, gambar, dan komik terbukti efektif untuk meningkatkan keterampilan pengambilan keputusan.

Berdasarkan hal tersebut di atas, modul program smart buying ini memiliki validitas isi yang baik dan penyusunannya disesuaikan dengan karakteristik mahasiswa. Modul ini dapat diuji cobakan pada kelompok mahasiswa untuk meningkatkan keterampilan pengambilan keputusan pembelian dalam mencegah penipuan belanja daring dengan beberapa saran perbaikan. Saran perbaikan digunakan untuk menyempurnakan modul agar lebih baik dan siap untuk diuji cobakan.

Berdasarkan saran perbaikan yang diberikan validator, psikolog industri memberikan saran untuk membangun proses building raport yang sesuai dengan kebutuhan pelatihan kepada peserta. Menurut Yates (dalam Anjani et al., 2020) Building Rapport memiliki tujuan untuk membangun suasana pelatihan agar peserta memiliki gambaran isi pelatihan, mengetahui manfaat yang akan diperoleh dari pelatihan dan agar peserta mampu 
memahami arah dan tujuan yang jelas mengenai target yang ingin dicapai. Atas saran ini untuk membangun suasana pelatihan peneliti menambahkan sebuah kegiatan building rapport dengan membuat sebuah game diawal kegiatan yang berhubungan dengan topik penelitian agar peserta memiliki gambaran yang jelas mengenai tujuan dari kegiatan.

Selanjutnya psikolog industri dan organisasi juga memberikan saran yaitu penggunaan kata-kata asing diubah ke bahasa Indonesia agar dapat dipahami oleh pembaca, tambahkan penjelasan mengenai masing masing sesi dengan lebih jelas, Pada agenda kegiatan masukkan waktu dan peralatan yang berfungsi untuk panduan bagi fasilitator.

Sama seperti psikolog industri, psikolog pendidikan memberikan saran pada peneliti terkait modul yaitu tambahkan kriteria fasilitator yang memiliki kemampuan bahasa yang baik dan efektif untuk menarik perhatian peserta. Hal ini menjadi penting dalam proses pelatihan, sesuai dengan penelitian Irgananda \& Widodorini (2017) fasilitator yang memfasilitasi diskusi kelompok dengan mengajukan pertanyaan dalam bahasa yang dapat dimengerti oleh mahasiswa menjadi faktor yang berpengaruh terhadap keefektifan diskusi kelompok PBL sehingga memiliki kemampuan bahasa yang baik menjadi peran yang efektif bagi fasilitator.

Berdasarkan hasil uji validasi modul terdapat penilaian dengan kategori cukup pada sesi kedua. Hal Ini dikarenakan gambar yang ada hanya menampilkan sedikit ciri-ciri penipuan belanja daring sehingga tidak menggambarkan dengan lengkap ciri toko penipuan telah disampaikan pada sesi pemberian informasi. Menindaklanjuti hal tersebut, peneliti melakukan perbaikan isi modul terutama padas sesi kedua tersebut dengan mencari toko daring yang telah melakukan penipuan dan menggambarkan toko daring yang telah menipu secara lengkap berdasarkan sesi pemberian informasi, serta mengkonsultasikan kembali bersama validator, dengan demikian program ini walaupun salah satu sesi dalam modul ini terdapat penilaian dengan kategori cukup, modul ini telah melewati proses validasi yang intens bersama validator.

Semua saran perbaikan yang didapatkan dari validator dalam penelitian ditindak lanjuti dengan melakukan revisi modul sehingga didapatkan produk akhir berupa modul program smart buying untuk meningkatkan keterampilan pengambilan keputusan pembelian konsumen dalam mencegah penipuan belanja daring pada mahasiswa yang telah memenuhi kriteria kelayakan baik dari aspek validitas isi. Dengan demikian modul yang telah dihasilkan ini diharapkan dapat membantu melatih keterampilan pengambilan keputusan konsumen mahasiswa dalam melakukan pembelian guna mencegah penipuan belanja daring

\section{Kesimpulan}

Berdasarkan hasil penelitian uji validitas modul program smart buying untuk meningkatkan keterampilan pengambilan keputusan pembelian untuk mencegah penipuan belanja daring pada mahasiswa, maka dapat diambil kesimpulan sebagai berikut :

1. Modul program smart buying berada pada tingkat validitas isi yang baik, artinya terdapat kesesuaian isi atau materi dalam tiap sesi modul program smart buying dengan tujuan yang hendak dicapai.

2. Hasil validasi modul yang dinilai oleh validator pada setiap sesi dalam modul program smart buying memiliki rentang skor sesi 1 yang bergerak dari angka $0,67-0,83$, sesi 2 dengan rentang angka 0,58-0,75 dan sesi 3 dengan angka 0,67 .

3. Hasil validasi modul yang dinilai oleh validator menunjukkan rentang angka skor $\mathrm{V}$ bergerak dari angka $0,58-0,83$ dengan kategori tinggi sampai sangat tinggi. Tiap sesi dalam modul program 
Uji Validitas Isi Modul Program Smart Buying untuk Meningkatkan Keterampilan Pengambilan Keputusan Pembelian Konsumen dalam Mencegah Penipuan Belanja

smart buying memiliki isi yang baik dengan rentang skor di atas 0,50 .

4. Hasil validasi alat ukur yang dinilai oleh validator menunjukkan rentang angka skor $\mathrm{V}$ bergerak dari angka 0,25-0,83 sehingga menunjukkan bahwa terdapat 5 butir instrumen alat ukur dengan kategori rendah, 8 butir instrumen alat ukur dengan kategori cukup, 6 butir instrumen alat ukur dengan kategori tinggi dan 3 butir instrumen alat ukur dengan kategori sangat tinggi berdasarkan uji validasi alat ukur pula terdapat 1 aitem instrumen alat ukur keterampilan pengambilan keputusan pembelian konsumen yang gugur.

\section{Saran}

Berdasarkan hasil penelitian yang telah dicapai serta mengingat masih banyaknya keterbatasan dalam penelitian ini, maka peneliti memberikan beberapa saran sebagai berikut: Pertama, saran bagi pemerintah, agar instansi pemerintah mulai responsif dalam membuat program atau kebijakan yang berfokus untuk melatih keterampilan konsumen dalam melakukan transaksi pembelian. Sedangkan untuk mahasiswa hasil penelitian ini diharapakan dapat memberikan pengetahuan dan keterampilan pengambilan keputusan pembelian guna mencegah penipuan belanja daring. Serta yang terakhir bagi peneliti selanjutnya untuk dapat mengembangkan program smart buying ini dengan memperluas karakteristik subjek penelitian, tidak hanya sebatas penipuan belanja daring pada mahasiswa.

\section{Daftar Pustaka}

Amelia, T. N. (2016). Fraud in Online Transaction: Case of Instagram. Journal of Advanced Management Science, 4(4), 347-350. https://doi.org/10.12720/joams.4.4.34 7-350

Ananda, L. D. (2018). Dinamika Trust pada Pemasaran Online di Media Sosial. Jurnal Komunikasi Indonesia, 6(1). https://doi.org/10.7454/jki.v6i1.8625

Anjani, W. S., Arumsari, C., \& Imaddudin, A. (2020). Pelatihan Self Management Untuk Meningkatkan Disiplin Belajar Siswa. Journal of Innovative Counseling: Theory, Practice \& Research, 4(1), 41-56.

APJII. (2016). Infografis Penetrasi \& Perilaku Pengguna Internet Indonesia.

APJII. (2019). Infografis Penetrasi \& Perilaku Pengguna Internet di Indonesia.

Azwar, S. (2018). Metode Penelitian Psikologi. Pustaka Belajar.

Button, M., Nicholls, C. M. N., Kerr, J., \& Owen, R. (2014). Online frauds: Learning from victims why they fall for these scams. Australian and New Zealand Journal of Criminology, 47(3), 391-408. https://doi.org/10.1177/00048658145 21224

Irgananda, citra insani, \& Widodorini, T. (2017). Pengaruh Kualitas Skenario Dan Peran Fasilitator Terhadap Keefektifan Diskusi Kelompok Problem-Based Learning. 4(1).

Iskandar, S. M. (2014). Pendekatan Keterampilan Metakognitif dalam Pembelajaran Sains di Kelas. Jurnal Pijar MIPA, 13(2), 86-89.

Jaya, D. C. (2012). Peran Kepercayaan dalam Perilaku Pelanggan untuk Meningkatkan Penjualan Secara Online. Jumma, 1 No.4. http://journal.wima.ac.id/index.php/J UMMA/article/view/362

Kure, E. (2016). 26\% Konsumen Indonesia Jadi Korban Penipuan Daring. http://www.beritasatu.com.

Kurniawati, E., Atmoko, A., \& Chusniyah, T. (2018). Analisis Penggunaan Media dalam Pelatihan Pengambilan Keputusan Moral di SMA. Jurnal Pendidikan: Teori, Penelitian, Dan 
Pengembangan, 3(9), 1128-1132.

Lorains, M., Ball, K., \& MacMahon, C. (2013). An above real time training intervention for sport decision making. Psychology of Sport and Exercise, 14(5), 670-674. https://doi.org/10.1016/j.psychsport.2 013.05.005

Maloney, J. (2007). Children's roles and use of evidence in science: An analysis of decision-making in small groups. In British Educational Research Journal (Vol. 33, Issue 3). https://doi.org/10.1080/01411920701 243636

Munandar. (2014). Psikologi Industri dan Organisasi. Universitas Indonesia.

Noe, R. A. (2009). Strategic Training and Development: Companion to Strategic Human Resource Management. 262-284.

Nurwita, I. (2015). Perancangan Kampanye Waspada Penipuan Saat Belanja Online the Design of Cautious Campaign. 2(2), 728-738.

Office of Fair Trading. (2009). The Psychology of Scams: Provoking and Committing Errors of Judgement.

Putra. (2019). OJK Catat 19.000 Aduan Penipuan Belanja Daring Karena Barang Tak Dikirim. http://www.merdeka.com

Rusmana, A. (2015). Penipuan Dalam Interaksi Melalui. Jurnal Kajian Informasi \& Perpustakaan, 3(2), 187-194. https://doi.org/10.24198/jkip.v3i2.99 94

Santrock, J. W. (2012). Life Span Development: Perkembangan Masa Hidup (Tiga Belas). Erlangga.

Schweizer, G., Plessner, H., Kahlert, D., \& Brand, R. (2011). A video-based training method for improving soccer referees' intuitive decision-making skills. Journal of Applied Sport Psychology, 23(4), 429-442. https://doi.org/10.1080/10413200.20 11.555346

Siswoyo, D. (2007). Ilmu Pendidikan. UNY Press.

Sugiyono. (2017). Metode Penelitian Pendidikan Pendekatan Kuantitatif, Kualitatif, dan $R \& D$. Alfabeta.

Sugiyono. (2019). Metode Penelitian Pendidikan (Kuantitatif, Kualitatif, Kombinasi, $R \& D$ dan Penelitian Pendidikan). Alfabeta.

Sumenge, M. monica. (2013). Penipuan menggunakan media internet berupa jual-beli online. Lex Crimen, 2(4). 